\title{
Bridging promises and (dis)illusions: \\ Deliberative democracy in an evolutionary perspective
}

\author{
Luigi Pellizzoni (University of Trieste) \\ luigi.pellizzoni@dispes.units.it
}

Author's final version of a chapter published in: Evolutionary Governance Theory. Theory and

Applications, edited by R. Beunen, K. Van Assche, and M. Duineveld. New York: Springer, 2015. pp. $215-232$

\begin{abstract}
The participatory, and especially deliberative, turn is a major political phenomenon of last decades. Deliberative democracy has spread quickly, regardless of differences in institutional layouts and traditions. An equally fast-evolving debate has addressed its virtues and problems, gradually shifting from theory to practice and from a focus on deliberative arenas to a concern for their policy and institutional context, the latter being implicitly or explicitly referred to the emergence of new governance styles. More recently a different critical literature has emerged, which adopts a governmentality perspective to argue about the inclusion of participatory democracy in neoliberal forms of regulation. The chapter illustrates major points of contention between these two literatures and considers some attempts at merging them, with related problems. Finally, it addresses the potentials of evolutionary governance theory as a framework for bridging diverse approaches to the promises and perils of participation.
\end{abstract}

Keywords: participation, deliberative democracy, governance, governmentality, neoliberalism, evolutionary governance theory

\section{Introduction}

The flourishing of participatory, and especially deliberative, democracy represents a major political phenomenon of last decades. Deliberative forums are structured arenas where different categories of people ('lay citizens', experts, public administrators, stakeholders of various sorts) 
meet to dialogically address 'public issues' of any size and topic - from the adoption of the European currency or the national policy on nanotechnologies to the layout of a road or the siting of a waste repository. Improved democratic legitimacy, social inclusion and cohesion are frequently sought by-products of these discussions.

Deliberative democracy has spread quickly, regardless of differences in political and administrative traditions. This success is reflected in a fast-growing debate. In this chapter I address an emergent line of division therein. Mainstream scholarship deals with the virtues and problems of public deliberation without questioning its fundamentally benign nature and implications for democracy. This, however, is precisely what a growing, alternative literature argues. In what follows ${ }^{1}$ I dwell on major points of contention between these outlooks (first two sections), showing that they build on diverging conceptualizations of the transformations in the ways of governing, according to either a 'governance' or a 'governmentality' framework. Recent attempts at combining them are not without problems (third section). Evolutionary governance theory (EGT), then, stands as a promising bridging framework. A thorough assessment of its potentialities is beyond the scope of this contribution. The last sections are devoted to a first exploratory inquiry, focused on some qualifying elements of EGT vis-à-vis deliberative democracy’s dilemmas.

\section{The mainstream approach to deliberative democracy}

Deliberative democracy, as a theory and a series of related practices, begins to develop in the 1980s, in reply to a much-lamented crisis of legitimacy or 'overload' of the democratic state parliamentary democracy, neo-corporatist arrangements, Welfare services and Fordist economy (cf. Held 1996). Central to deliberative theory and related practices is the notion of public interest or common good and the active engagement of people in well-identifiable (physical or virtual) arenas, where individual citizens or stakeholders meet and discuss according to clear sets of questions and procedures, in search of agreed solutions to their problems. Beside conceptual elaborations (cf. e.g. Bohman and Rehg 1997; Habermas 1996; Elster 1998), scholars soon begin to focus on how deliberative forums actually operate, and how they may get as close as possible to the normative ideals of deliberation. Along the years substantial efforts are devoted to filling the gap between theoretical discussions and empirical explorations (e.g. Steiner et al. 2004; Rosenberg 2005; Mutz 2008; Thompson 2008). A number of models are developed, tested and systematized (e.g. Gastil and Levine 2005). The role of self-interest, group dynamics, will manipulation, bargaining and negotiation and the problems of preference change and collective choice are addressed, leading to

\footnotetext{
${ }^{1}$ Some parts of this chapter are reworked from Pellizzoni (2013).
} 
growing 'realism' or 'tolerance' in the definition and implementation of the deliberative ideals (e.g. Dryzek and List 2003; Hendriks 2006; Niemeyer and Dryzek 2007; Rosenberg 2007; Mansbridge et al. 2010).

The link between deliberative democracy and its policy context gains salience as well (e.g. Fung and Wright 2003; Parkinson 2006; Goodin and Dryzek 2006), partly as a consequence of limited but significant institutionalization of deliberative forums ${ }^{2}$. Beside problems of design and internal working, it is obviously crucial how deliberative processes fit into, and the effects they produce onto, a policy environment that is undergoing major transformations. For many, deliberative democracy is actually a major expression of this change. If 'governance' is the transfer of power from state to non-state actors, from single actors to networks, from law to market and quasi-market mechanisms, from a democracy of conflict and representation to a democracy of efficiency and stakeholder interests and concerns, then deliberative forums include most, if not all, the tropes of governance (e.g. CEC 2001; Hajer and Wagenaar 2003; Sørensen and Torfing 2005). Tensions with representative democracy and limited impacts on actual decisions are generally read as problems of design and institutional harmonization, amenable to gradual solution (e.g. Van Mill 1996; Dryzek 2001; Van Eeten 2001).

The contrast between earlier accounts of participatory democracy, where participation was usually understood as a bottom-up, self-organized, contentious process, involving pre-existing collectives and often broad in scope (Pateman 1970), and deliberative scholars' favour for topdown, structured, single-issue, consensus-oriented approaches is ascribable, to a significant extent, to the inscription of deliberative democracy in the framework of governance. If the state is no more the central source of power and the addressee of material or symbolic claims, if it increasingly appears to be just one among autonomous (if interdependent) public and private entities, then the risk of technocratic or populist drifts, inbuilt in 'governed' mobilizations, loses much of its former relevance. Main issue becomes, rather, how to ensure democratic legitimacy and operational efficacy to decisions taken within an increasingly messy policy environment. In this sense, even those criticisms (often coming from rational choice-inspired scholars) which stress the unrealistic or untestable assumptions of deliberative theory and the openness of dialogical processes to manipulation, rarely question the fundamentally benign character of deliberative democracy. There is nothing intrinsically ill-fated or programmatically distorted in it. Despite drawbacks and misuses,

\footnotetext{
2 Apart from the European Union's growing commitment to 'partnership' and participation (of which the 2007 Lisbon Treaty describes no less than four types: expression and exchange of views, dialogue, consultation, and citizens' right of initiative), one should mention at least the French 1995 law on the débat public (Revel et al. 2007) and the cross-country diffusion of participatory budgeting (Sintomer and Allegretti 2009).
} 
public deliberation is a valuable way to make up for the limits of traditional representative mechanisms and administrative styles, faced with growing social complexity.

Recently, scholars' outlook has been broadening to address 'deliberative systems' (Parkinson and Mansbridge 2012; Steiner 2012) - the overall democratic performance of entire nations or regions, as affected by their specific institutions, political cultures and social divisions. The assumption, however, remains that, if 'properly' understood and applied, more deliberation means more democracy, social cohesion, policy effectiveness, and so on.

In short, despite a number of differences in approach ${ }^{3}$ and assessment, the literature discussed so far - which by any account constitutes the mainstream in this field, since it includes most prominent authors and fills a major part of academic and policy debates - shares a traditional understanding of the relationship between theory and practice (the first provides the latter with a benchmark or a critical compass) and a positive view of public deliberation in the context of emerging forms of governance.

\section{The alternative approach}

It is against this background that a major alternative approach has been gaining salience in recent years. Crucial to this outlook is not the question of how to 'improve' (in whatever sense) real world deliberative democracy, but rather 'how did the deliberative turn become such, in terms of acquiring its seemingly snowballing impetus and intellectual credence' (Hobson 2009: 182). Moreover, this approach draws to a remarkable extent on 'radical democracy' perspectives (e.g. Rancière 1998; Mouffe 2005; Purcell 2008), for which political conflict (not necessarily violence, of course) is unavoidable while generalized consensus is an illusory, if not dangerous, ideal ${ }^{4}$. Conflict is not a starting point to be overcome, or an unfortunate by-product, as mainstream scholarship contends. It is an ever-present trigger and stake. Hence, it is not simply that deliberative forums can be used in a distorted way, or that the deliberativeness of a political system can vary. Rather, deliberative forums are to be regarded, also and perhaps first of all, as an additional means or arena of political struggle.

\footnotetext{
${ }^{3}$ Differences, for example, between those who understand deliberative processes as a means to build and express in a 'better', more 'reflective', way the public opinion (hence random selection of participants is advisable), and those who understand them in a Deweyan fashion, as a means to perform public inquiries into collective problems (hence 'reasoned' choice among the involved parties is preferable).

${ }^{4}$ According to Besson and Martí (2006), authors like Mansbridge and Dryzek seek to accommodate deliberative democracy with radical approaches. However, recognizing the need for deliberative theory to take in consideration the reality of conflict and self-interest does not amount to joining a Marxian, Schmittian or Foucauldian understanding of the political as based on, rather than affected by, conflict. On this point cf. also Silver et al. (2010).
} 
This standpoint emerges clearly, for example, in a study about two Electronic Town Meetings (ETMs) $^{5}$ organized in 2006 and 2007 by the regional government of Tuscany (an Italian region of centre-left administrative traditions).Topics under discussion were, respectively, defining general guidelines for a regional law on participation ${ }^{6}$, and deciding about citizens' contribution to health spending (the budget in discussion was around $1.8 \%$ of the regional health fund). The authors of the study (Freschi and Mete 2009) address the way these processes have been organized and implemented with an eye on their underlying political stakes - basically, as they argue, the need for the ruling political elite to control the discontent of its constituency, giving it a feeling of 'empowerment', while steering clear from major contentious issues and keeping a direct line of negotiation with organized interests. Another study, again based in Tuscany but on different cases, argues that the deliberative arenas analysed did not carve out spaces sheltered from the dynamics of contentious politics, but rather created hybrid frameworks where different logics contaminated each other, adding complexity to the political landscape (Lanzara and Lupo 2013).

This perspective is shared by a growing corpus of studies, dealing especially with two fields. The first is local, and particularly urban, governance. The comparison of deliberative experiences in various European countries edited by Papadopoulos and Warin (2007), or the analyses carried out by Barnes et al. (2007) and Newman and Clarke (2009) for UK, by Sintomer and De Maillard (2007) and Blatrix (2009) for France, and by Bobbio and Pomatto (2007) and D'Albergo and Moini (2007) for Italy, portray a landscape of weak policy impacts as a result not so much of poor harmonization with traditional institutions of democracy, as of purposeful, systematic hollowing out or perversion of its potentials. Another major field of experiments in public deliberation is technoscience and environment governance. One can observe here 'a strange confluence at which processes of public participation and deliberation have almost become orthodoxy, whilst simultaneously great scepticism is being pronounced about them' (Tsouvalis and Waterton 2012: 113) - and this, often, by their former advocates and promoters. Again, criticisms do not point to imperfect or compromised implementation of deliberative democracy, but to systematic distortions of its basic aims (e.g. Hagendijk and Irwin. 2006; Levidow 2007; Lezaun and Soneryd 2007; Wynne 2007; Pestre 2008; Felt and Wynne 2007; Lövbrand et al. 2011; Irwin et al. 2013).

\footnotetext{
${ }^{5}$ The ETM technique seeks to combine the advantages of small-group debate with those deriving from the involvement of a larger number of citizens. A group of people varying from some hundreds to some thousands are divided into subgroups of about ten to discuss an agenda of issues at separate tables. By means of network-connected computers, the results of individual discussions are collected, aggregated and reported to all participants, who then have to vote on questions related to the issues discussed.

${ }^{6}$ The law has been subsequently passed on 27 December 2007 (Regional Law No. 69/2007). A renewed version has been passed on 24 July 2013 (Regional Law No. 46/2013).
} 
The opposed reading that the alternative literature provides of well-known tropes of mainstream narratives of deliberation is instructive. Take for example the alleged benefits of 'designed' participation. Instead of offering a ground for constructive dialogue, the fact that problem-definition and agenda-setting powers are held by specific actors leads easily - it is argued - to restricting or pre-empting the scope of discussion, in order to ward off controversy. For this reason the 'innocent', 'ordinary' citizen, 'not contaminated with the corruption, collusion and cynicism of existing politics' (Clarke 2010: 640), is typically preferred to people with clear, well-grounded ideas and opinions. According to these readings, moreover, middle-class and elite interests are systematically favoured (Melo and Baiocchi 2006). The inclusion of weaker groups, more than aimed at promoting their empowerment (which arguably would entail addressing underlying class, gender or race inequalities before, or at least together with, the activation of deliberative processes), seems a way to manage potential troubles and produce consent under the fiction of an equal share in the decision power (Blakeley 2010). In short, supposedly empowered constituencies find themselves legitimating decisions with which they actually disagree, or that produce limited redistributive effects (Silver et al. 2010). More generally, participants are drawn to agree on decisions dictated by 'evidence' of problems and facts, with consequent marginalization or exposure to blaming of those who disagree with the way such evidence is produced. In addition, 'the general public or the community [is] portrayed as one of a number of stakeholders in some sense entitled to be party to the dialogue' (Goven 2006: 104). The fragmented state of society, thus, is simultaneously presumed and produced. This also thanks to the widespread assumption that deliberation takes place first and foremost in the individual 'internal forum' (Goodin 2000). Most problematic, for its depoliticized conception of democracy, is found to be another basic tenet of mainstream deliberative theory: that public deliberation should be closer to a judicial assessment aimed at impartially defining the interest of all than to a political confrontation aimed at defining the general interest - which arguably means making some interests prevail over others, albeit in a publicly justified manner (Urbinati 2010).

From an evolutionary or historical perspective, the most telling divergence between mainstream and alternative scholarships is in regard to their reading of the relationship between deliberative democracy and governance. The mainstream literature assumes a profound difference between the logic of governance, based on the composition of organized interests, and the rationale of deliberative democracy, focused on supporting weak groups and neglected issues (e.g. Fung 2004; 2006). Hence the latter is seen to play a counterbalancing or complementary role. The broadening space for participation and deliberation within networks is read as a new genre of 'collaborative' or 'organic' governance (EC 2000; Ansell and Gash 2007; Fischer 2010). The alternative literature, on the contrary, understands this trend in functional or subordinate terms; that is, as a way to 
strategically respond to, or smooth, the potential troubles coming from managerial approaches, exclusionary stakeholder negotiations, unequal resource distribution, social expenditure cuts and low levels of accountability (Pestre 2008; Moini 2012).

\section{Governance vs. governmentality}

At closer inspection the reason of this divergence is evident. Mainstream scholarship, as said, looks at deliberative democracy from the vantage point of a political model in decline, for this reason in need of constant injections of democratic liveliness. The rise of deliberative democracy is accounted for according to a narrative by which major socio-economic changes (often synthesized in the word 'globalization') have affected the legitimacy and effectiveness of traditional arrangements, dictating a shift to a different sort of rule - governance - which provides new meanings to, and opportunities/risks for, democratic participation. The alternative reading, instead, frames the diffusion of participatory democracy in the context of what it considers to be the winning reply to the crisis of the traditional order: namely, the advent of neoliberalism.

In this sense 'radical critiques of deliberative democracy frequently appear [...] as critiques of "neoliberal governance", (Silver et al. 2010: 461). Neoliberalism is central as much to theoretical literature (e.g. Mouffe 2005; Goven 2006), as to contributions devoted to analysing concrete participatory processes, especially at urban level (e.g. Barnes et al. 2007; Guarneiros-Meza and Geddes 2010) ${ }^{7}$. Accordingly, the interpretive framework shifts (more or less explicitly) from 'governance' to governmentality'. As it is well-known, Foucault uses this term in both an analytical and historical sense. Governmentality is the ensemble of institutions, procedures, techniques and ways of thinking around which the exercise of power is articulated; yet it is also the growing preeminence, in modern political history, of government over other forms of rule (sovereignty, discipline). It is, in other words, the increasing focus of political power on the handling of people and their biophysical environment in an allegedly useful (productive, enhancing) direction, hence mainly according to an economic rationality and through apparatuses of security (Foucault 1991). Neoliberalism, then, represents an intensification of these traits; an intensification, however, where

\footnotetext{
${ }^{7}$ Cities play a growing role in managing the interface between local economy and global flows, local sustainability and international competitiveness, social exclusion and global polarization (Jessop 2002). Hence, it comes as no surprise if it is at urban level that the instrumentality of participatory processes to the stabilization, deepening and strengthening of neoliberalism is most frequently assessed.
} 
'the lightening, saturation, becoming-more-efficient, and transversal linkage of existing practices' (Nealon 2008: 38) entails at some point a qualitative shift ${ }^{8}$.

Whereas the literature on governance generally builds on traditional views of power, authority and legitimacy, focuses on rules and institutions, and assumes that the objects of governmental action pre-exist the latter, the governmentality approach pays greater attention to practices and the role played therein by what Foucault (1980) calls governmental dispositifs - the network of narratives, knowledges, beliefs, texts, operational technologies, that simultaneously constitute government and its subjects/objects (Dean 1999). As a consequence, opposed readings are given of the same historical process. Governance is not simply 'an instance of transfer of power from the state to non-state actors, [but] an expression of a changing logic or rationality of government' (Sending and Neumann 2006: 652). And it is precisely such change in rationality that, rather than being its consequence, triggers new social and economic arrangements. On this view, we are not simply in front of a redistribution of power, but of the advent of new forms of rule, to which social science technologies and expertise (including deliberative theories and techniques) actively contribute, crafting the subjectivities and realities they are supposed to describe or handle 9 .

In this way deliberative democracy finds itself caught in the broader, enduring controversy between governance and governmentality scholarships (Pellizzoni 2012). The former contends that the latter's structuralist inclinations lead to downplaying agency and to reified, monolithic accounts of power, with harmful effects on its analytical grip. The governmentality approach is allegedly characterized by a general 'hostility to humanism and agency'; by the belief that 'epistemes or regimes of power-knowledge define, or at least limit, the intentions people can have'; and by a focus 'on how social practices and traditions create forms of subjectivity to the apparent exclusion of the ways in which agents create social practices and traditions', with consequent 'problems in accounting for change' (Bevir 2007: 39, 40, 43; cf. also Bevir and Trentmann 2008). Hence it provides also an unwarrantedly pessimistic account of new forms of participation. In their turn, governmentality scholars maintain that discourses of choice and empowerment belong to a 'broad

\footnotetext{
${ }^{8}$ Think, in this sense, of the way neoliberalism 'overcomes' liberalism. The former maintains the need to extend economic rationality to all social fields - rather than ensuring a space for economy free from political or religious influences. It maintains as well that markets are artificial institutions which have to be purposefully constructed, steered and policed in order to promote humans' natural tendency to compete - against the liberal understanding of the market as a self-regulating institution, under the assumption of human natural tendency to exchange (Tickell and Peck 2003; Dardot and Laval 2009).

${ }^{9}$ From this perspective, the criticisms that deliberative democrats (and governance scholarship) address to the cognitive deficits of representative institutions and traditional bureaucracies can be read as a clue to the hegemonic status of neoliberalism, its basic tenets about the state's limited capacity of steering getting support from ostensibly opposed quarters.
} 
hegemonic agenda of neoliberal restructuring' (Malpass et al. 2007: 234). They complain about the 'neoliberalization of activism' (Roff 2007: 561): the translation of contentious politics into a narrative of 'active', 'responsible' citizenry. From this viewpoint deliberative (and generally participatory) democracy becomes a crucial element of the governmental dispositifs that characterize neoliberal rule.

On closer view, one realizes that the governance literature clashes especially with those governmentality approaches which borrow significantly from Marxian political economy (e.g. Lemke 2003, 2007; Raman and Tutton 2010, Bröckling et al. 2011), arguing that neoliberal dispositifs are the result (if partially or even largely unintended and uncontrolled) of specific strategies, aimed at restoring class power and enabling renewed capital accumulation. Other Foucauldian scholarship - including prominent authors like Nicholas Rose (e.g. 1999; 2007) explicitly refrains from using the term neoliberalism and depicts in a more balanced, or agnostic, way the risks and opportunities of new forms of engagement.

In any case, the contrast between governance and governmentality seems recently amenable to a reconciliation; a sort of synergy or cross-fertilization. After all, both governance and governmentality relate 'power and the state to processes, exchanges and interactions with various practices and actors in civil society' (Bevir 2011: 460). Moreover, one can detect theoretical and empirical convergences between 'interpretivist' approaches to governance, sensitive to mentalities and rationalities of rule, and historicist or genealogical approaches to governmentality, which (contrary to structuralist or archeological ones) are sensitive to agency and the fluidity of power/knowledge assemblages (Bevir 2010; Richardson 2011).

A significant convergence between governance and governmentality occurs as regards the role of discourse. From a governmentality viewpoint, more than a medium of exchange of meanings to be used more or less honestly, respectfully and skilfully, discourse is 'at the heart of constitution of both the individual political subject and the field of politics' (Hobson 2009: 185, italics original). Yet the centrality of discourse as trigger and outcome of particular mentalities of government is acknowledged also by scholars adhering to a governance perspective, who 'treat patterns of rule as constituted by distinct mentalities' (Bevir 2011: 461) and stress the limits of assumptions about 'sound' or inefficient behaviours, or about the neat distinguishability between factual evidence and principled orientations (cf. Richardson 2011: 537). When applied to deliberative or participatory processes, these lines of convergence point to acknowledging the importance of an analysis in terms of governmental strategies, while contesting encompassing, hegemonic accounts of the latter. For example, John Clarke remarks that 'the proliferation of strategies for enrolling "ordinary people" into governing the social [cannot be] reduced to the corrupt fruit of neo-liberalism as it enlarges its scope or reach' (Clarke 2010: 638). Stigmatizing 'collaborative governance' as just functional to the 
extension of the neoliberal project leads to neglecting other politics, the coexistence of multiple tendencies and complex relations between them. More than neoliberal rule, then, one should talk of governmental assemblages, where ordinary people are not always reduced to self-governing economised subjectivities, but 'are also invited to become co-producers of welfare, care, community and the "social fabric"” (Clarke 2010: 641).

In this way governance and governmentality are putatively reconciled. Turning away from Marxian underpinnings and towards Deleuzian ontologies, a case is made against those readings which frame participation within the alleged 'post-political' tendencies of neoliberal hegemony, to the detriment of detailed analyses of actual practices - the messy, everyday interactions and negotiations among heterogeneous actors. Practices, moreover, where materialities of any sort (land, space, technical devices of communication, metering units of energy consumption, and so on) play no lesser a role than discourses and arguments in the enactment of agential assemblages (McKee 2009; Marres and Lezaun 2011; Fuller 2013).

Yet can governance and governmentality be harmonized so neatly? Possibly not. From a governmentality viewpoint, even the attribution to ordinary citizens of powers of agenda or their margins of unpredictability have to be gauged against the acknowledgment that deliberative democracy is enacted through, and expresses, particular rationalities and techniques of government (which include many alleged 'self-enacting' materialities), provided with a constitutive, rather than just enabling or constraining, power over subjectivities and problematizations. Basic point of contention with governance scholarship remains the extent to which this heteronomous element in the constitution of the self, of one's own interpretive and motivational frameworks, can be transcended through a deliberate individual act of will. Clarke's own analysis confirms the relevance of this problem. On one side, 'ordinary people are valorised because they are not political' (Clarke 2010: 642, italics original) - hence, their mobilization as the medium or agent in the government of the social is built on, and simultaneously triggers, the depoliticizing drift on which (according to governmentality scholars) neoliberal practices and much deliberative theory converge. On the other, ordinary people are not simply 'found' but actively constructed - selected, instructed and inducted 'into the expectations of their performance' (Clarke 2010: 647). The production of 'ordinariness' is what Foucauldian scholarship regards as the quintessential performance of normalization strategies. It might well be, then, that the whole discourse of 'empowerment' is compromised, being integral to the governmental logic of neoliberalism, the eventual result of collaboration and participation being to help produce 'new forms of governable subjects' (Newman 2005: 120).

A light-hearted use of elements drawn from governance and governmentality scholarships, therefore, is likely to meet with major inconsistencies. The basic issue is that, from a 
governmentality viewpoint, governance is not an alternative or complementary conceptual framework, but a primary object of inquiry, for it represents a crucial expression and trigger of new mentalities of government. Moreover, the typical objection against the Foucauldian approach - if there is no true discourse but only truth games, why should governmentality enjoy any higher veridical status than governance? - misses its basic point. Governmentality does not aspire at presenting accounts grounded on some transcendental vantage point which would ensure them a higher truth-value. It is a genealogical reconstruction: the vantage point is therefore fully internal to the historical events discussed, and to the engaged position of the analyst (Owen 1999). I will come back later to this issue.

\section{EGT as a bridging framework}

To sum up, we are in front of two significantly contrasting readings of the spread of deliberative democracy in the last decades. Worse, these readings are hardly comparable or combinable in a straightforward manner because of their fundamental divergence in rationale. What is happening with deliberative democracy in our current political arrangements? How are we to assess the layout, management and outcome of actual deliberative processes? Can deliberative democracy and other forms of 'empowered' citizenship be a way to resist neoliberal post-political drifts, or not? And is neoliberalism a suitable analytical perspective, or does it trigger biased accounts which obscure the potentials of new ways of participating? Addressing this sort of questions is hardly helped by a clash of incompatible theoretical standpoints.

EGT stands here as a promising framework for conducting a more fruitful conversation. Its immediate attractiveness comes from its sharing elements of both governance and governmentality approaches (Van Assche et al. 2013). EGT explicitly belongs to the family of governance studies, not so much for its name as for its taking, as a point of departure, recent and ongoing major transformations in the way collectively binding decisions are taken, without assuming a unique analytical perspective or strong normative standpoints. This interpretive 'neutrality' manifests itself in EGT's borrowing from different theoretical traditions and in its taking distance from the opposed mythologies of free market and centralized planning. The relevance of the governance perspective for EGT emerges also from its particular attention to the interweaving of actors and institutions, as triggering at the same time path dependency and potentiality for change. However, EGT shares with governmentality at least three important aspects: a) a poststructuralist, and specifically Foucauldian, emphasis on the centrality of language and discourse, with its performative effects on behavioural regulation, as well as on the inseparability of power and knowledge, rule and sense-making of 
reality; b) an element of reflexivity, by which theory has to elaborate first of all on its own limitations, its blind spots in accounting for change; c) an understanding of power as a distributed and 'productive' property of all relationships, based on the actors' freedom, rather than an attribute of some of them, used to constrain the behaviour of others.

This combination of elements produces a first significant result in highlighting a point that the controversy between governance and governmentality tends to neglect. EGT, beginning with its own name, stresses the evolutionary character of governance arrangements, as triggered by the intertwining and feedback of their elements (institutions, discourses etc.). This is something on which mainstream deliberative scholarship, especially with its latest focus on deliberative systems (Mansbridge et al. 2012), insist. The Foucauldian outlook instead, as we have seen, is often blamed for its inability to account for change. Yet this is not necessarily the case. The governmentality critique of deliberative democracy can be strong but never completely destructive, since it conceives of power and resistance as strictly coupled - there is no power without resistance; power produces its own resistance, or resistance is an effect of power. In any historical process the 'dominant' and the 'effective' are always revealed and wrong-footed by the 'residual' and the 'emergent' (Williams 1977). In this sense, attempts at depoliticizing issues through forms of 'collaborative governance' may provide citizens and groups with novel opportunities of politicization (Clarke 2010). More in general, as power 'becomes increasingly more capillary, more invested in everyday matters and everyday lives, so too an immense new field of possibility for resistance is opened' (Nealon 2008: 107-108). Systematic distortion of public deliberation, in other words, does not mean impossibility to use it against its strategic enactments. In short, the evolutionary processes of governing offer a terrain on which governance and governmentality approaches can engage in a productive conversation.

Of the many other clues offered by EGT to improving the analytics of deliberative democracy, its stress on the relevance of narratives of success and failure likely bears a particular relevance. Definition and assessment of success or failure are central to both mainstream and alternative deliberative scholarships, as we have seen. Success or failure can be defined at the level of input (participants' selection, agenda setting etc.), throughput (deployment of the process) and output (actual policy impact) (Papadopoulos and Warin 2007). Yet the implied causality is reversed in the two cases. For mainstream scholarship input and throughput success (however defined) is premised on (if not sufficient to) the success of outputs. The same happens with failure, be it described in terms of futility (ineffectiveness of the process) or perversion (the process achieves results that are opposed to its alleged aims). A poorly organized or handled deliberation can hardly achieve valuable results, whatever its capacity to affect the policy context. For the alternative scholarship the opposite applies. The policy environment, with its unbalances in power and agency and to the 
extent that such unbalances are left untouched, backfires on the way the process works at input and throughput levels. Not only such unbalances are likely to be reproduced at these levels, but even the most inclusive and well-conducted deliberation can never offset - and actually may amplify - the unequal or unjust character its outputs assume once implemented in this context.

If we then combine EGT's simultaneous focus on evolution and on narratives of success and failure, and keep under control the opposed implied causalities of the two approaches, we should be able to improve our analytical grip on empirical cases. Let's go back to the example of alternative approach to deliberative democracy mentioned above - the analysis of two ETMs in Tuscany. Freschi and Mete's interpretation has been criticized on all three levels of measurement of success. At input level, Freschi and Mete contend that the participants in the first ETM (participation bill) consisted of a 'leftist elite', in contrast with the inclusive assumptions of deliberative democracy, whereas the participants in the second ETM (citizens' contribution to health spending) were selected randomly, intentionally bypassing existing conflicts and grass-root groups' mobilizations on themes involving the whole health care system (reorganization of hospital network etc.). Focusing on the first ETM, Antonio Floridia (2013) objects that the organizers never intended to build a group representative (in any sense) of the Tuscany citizenry, but an ensemble of motivated, interested people, and that a democratic deliberation does not necessarily occur among 'ordinary citizens'. At throughput level, Freschi and Mete contend that table discussions have been hampered by the exceedingly tight time allocated for them, whereas Floridia maintains that this has not prevented actual argumentative exchanges. Yet it is at the output level that the key contrast emerges. Freschi and Mete, as said, contend that the basic goal of the organizers was to use politically the ETMs in order to protect themselves against malcontent and regain legitimacy under the fiction of citizens' empowerment (the real stakes and conflicts were left unaddressed and even obscured). Accordingly, Freschi and Mete devote much space to analysing the political context of the two ETMs, arguing about its 'post-democratic' (Crouch 2004) sort of evolution in recent years. Floridia remarks that the political aim of the ETM on the 'participation bill' was explicit, as it was aimed not at developing a 'pure' discussion (which, according to him, Freschi and Mete assume to be the task of 'sound' deliberative processes), but at constructing an actual policy on the topic addressed.

What emerges from this comparison is a classic dialogue of the deaf. What the one regards as a success, for the others is a failure. What for the one is the logical sequence for assessing quality and success (set a clear policy goal, begin with input, then go to throughput and finally to output), for the others needs to be read in the opposite direction (begin from the political context, which gives a clue to the actual intentions and possibilities of the organizers, and then go back to analysing the process in all its aspects). And what for the one is perfectly justified (the 'biased' selection of 
participants), and moreover can hardly be ascribed to manipulative intentions (if participants were just a leftist elite, asks Floridia, how could the promoters think that the event would contrast the radicalness of most antagonist groups and increase or restore their legitimacy?), for the others, especially by confronting the first ETM with the second, confirms precisely this aim (politicians know that antagonists can never be captured, hence legitimacy can be regained or strengthened only within their own constituency; and when this constituency develops actual oppositional groups, their strategy is to break and marginalize them by involving 'ordinary' individuals in a discussion on minor issues).

An EGT outlook, then, may shed light on which interpretation is more correct or convincing. This task cannot be carried out here, of course, since it would require a reassessment of the data available on the two ETMs. Yet we can at least understand the direction to take. On one side, EGT's focus on performativity drives our attention to the way narratives of performance produced truth effects impinging on the way insiders and outsiders regarded the rationale and deployment of the processes. On the other, EGT's focus on change drives our attention to how the two issues, and the whole political context, have evolved subsequently. This entails analysing health care policy developments, the electoral and public sphere dynamics involving the political personnel and its constituency, and the effects produced by the implementation of the participation law - its degrees of success or failure (number, typology, outcomes of, and debates surrounding the supported processes), as well as the way the new version of the law seeks to address the perceived weaknesses of the first version ${ }^{10}$.

\section{Conclusion: a potential worth exploring}

In this chapter I addressed a major divide emerging in the literature on deliberative democracy. I argued that diverging interpretive frameworks underlie this division. One builds on a 'governance' reading of ongoing transformations in advanced democracies; the other draws on a 'governmentality' approach. I argued that current attempts at merging the two readings - benefitting from both and overcoming a certain amount of sterile quarrels - tend to underestimate the fundamental differences in the rationale of the two outlooks. I argued, finally, that EGT offers

\footnotetext{
${ }^{10}$ For example the original law put much emphasis on a deliberative model inspired to the French débat public, yet no such process took place. The new formulation includes more binding dispositions on this point. Information and materials on the Tuscany laws and experiences (mostly but not exclusively in Italian) can be found at the website of the Tuscany Regional Administration: http://www.regione.toscana.it/regione/istituzioni/partecipazione. An overall assessment is provided by Lewanski (2013). Cf. also Floridia (2008); Bobbio (2013).
} 
valuable opportunities for establishing a fruitful conversation, thanks especially to its focus on the performative role of discourse and on the constant evolution of governmental arrangements.

I could only scratch the surface of EGT's potentialities. Yet, as the example discussed suggests, they are worth exploring. This, of course, entails not only expanding the number and depth of empirical studies, but also elaborating further on EGT itself. In its present formulation a latent functionalism may perhaps be detected, as a consequence of the programmatic eclecticism of its theoretical sources and the avoidance of strong normative standpoints. This approach implies, for example, tacking stock of Foucault's notion of power, as distributed, 'productive' and based on actors' freedom, while leaving more in the shadow his account of domination, as a situation in which, through material-symbolic technologies, power relations crystallize in ways that are steadily asymmetrical and difficult to reverse (Foucault 1997a). Accounting for domination, however, is likely to entail more space for Marxian readings of current governmentality, as the (incomplete and partly unintended) result of neoliberal political projects. The normative neutrality of EGT, moreover, may entail a latent conflict with its own Foucauldian underpinnings, to the extent that inseparable from them is an explicit critical project - albeit not the traditional one of gauging the distance between reality and a transcendental ideal, but rather a critique grounded on the immanent, engaged question of 'how not to be governed like that, by that, in the name of those principles, with such and such an objective in mind and by means of such procedures, not like that, not for that, not by them' (Foucault 1997b: 44, italics original).

Undoubtedly, taking more markedly Foucauldian/Marxian standpoints entails a price, in terms of reduced theoretical inclusiveness and political agnosticism, and it is to be seen to what extent and in what form EGT scholarship is willing to follow this direction. Be it as it may, EGT represents a promising framework for bridging diverse readings of the hopes and perils of public deliberation, in the changing landscape of advanced democracies.

\section{References}

Ansell, C. and A. Gash (2008) Collaborative governance in theory and practice. Journal of Public Administration Research and Theory, 18 (4): 543-571.

Barnes, M., J. Newman and H. Sullivan (2007) Power, Participation and Political Renewal. Bristol: Policy Press.

Besson, S. and J.L. Martí (2006) Introduction. In: S. Besson and J.L. Martí (eds.) Deliberative Democracy and its Discontents. Aldershot: Ashgate, pp. xiii-xxxi. 
Bevir, M. (2007) The construction of governance. In: M. Bevir and F. Trentmann (eds.)

Governance, Consumers and Citizens. New York: Palgrave MacMillan, pp. 25-48.

Bevir, M. (2010) Rethinking governmentality: towards genealogies of governance. European Journal of Social Theory, 13(4): 423-441.

Bevir, M. (2011) Governance and governmentality after neoliberalism. Policy \& Politics, 39 (4): 457-471.

Bevir, M. and F. Trentmann (2008) Civic choices: retrieving perspectives on rationality, consumption, and citizenship. In: K. Soper and F. Trentmann (eds. ) Citizenship and Consumption. Basingstoke: Palgrave MacMillan, pp. 19-33.

Blakeley, G. (2010) Governing ourselves: citizen participation and governance in Barcelona and Manchester. International Journal of Urban and Regional Research, 34 (1): 130-145.

Blatrix, C. (2009) La démocratie participative en representation. Sociétés Contemporaines, 74 : $97-$ 119.

Bobbio, L. (2013) (ed.) La Qualità della Deliberazione. Processi Dialogici tra Cittadini. Roma: Carocci.

Bobbio, L. and G. Pomatto (2007) Modelli di coinvolgimento dei cittadini nelle scelte pubbliche. Report for the Provincia Autonoma di Trento.

Bohman, J. and W. Rehg (1997) (eds.) Deliberative Democracy. Cambridge, MA: MIT Press.

Bröckling, U., S. Krasmann and T. Lemke (2011) (eds.) Governmentality. Current Issues and Future Challenges. London: Routledge.

CEC (2001) European Governance. A White Paper. Brussels: Commission of the European Communities, Com 2001(428).

Clarke, J. (2010) Enrolling ordinary people: governmental strategies and the avoidance of politics? Citizenship Studies, 14(6): 637-650.

Crouch, C. (2004) Post Democracy. Cambridge: Polity Press.

D’Albergo, E. and G. Moini (2007) (eds.) Partecipazione, Movimenti e Politiche Pubbliche a Roma. Roma: Aracne.

Dardot, P. and C. Laval. (2009) La Nouvelle Raison du Monde. Essai sur la Société Néolibérale. Paris: La Découverte.

Dean, M. (1999) Governmentality. Power and Rule in Modern Society. London: Sage.

Dryzek, J. (2001) Deliberative Democracy and Beyond. Oxford: Oxford University Press.

Dryzek, J. and C. List (2003) Social choice theory and deliberative democracy: a reconciliation. British Journal of Political Science, 33 (1): 1-28. 
EC (2000) The Future of Parliamentary Democracy: Transition and Challenge in European

Governance. Green Paper. AS/D(2000). Brussels: European Commission. Available at : http://ec.europa.eu/governance/docs/doc3_en.pdf.

Elster, J. (1998) (ed.) Deliberative Democracy. Cambridge: Cambridge University Press.

Felt, U. and B. Wynne (2007) (eds.) Taking European Knowledge Society Seriously. Report for the European Commission. Luxembourg: Office for Official Publications of the European Communities.

Fischer, F. (2010) Participatory Governance. Jerusalem Papers in Regulation \& Governance. Working Paper No. 24.

Floridia, A. (2008) Democrazia deliberativa e processi decisionali: la legge della Regione Toscana sulla partecipazione. Stato e Mercato, 82: 83-110.

Floridia, A. (2013) Partecipazione, deliberazione e politiche pubbliche: soltanto inefficacia o manipolazione? Uno schema analitico e un caso di studio. Paper presented at the XXVII Conference of the Italian Association for Political Science (SISP). Florence: 12-14 September.

Foucault, M. (1991) Governmentality (lecture at the Collège de France, February 1978). In: G.

Burchell, C. Gordon and P. Miller (eds.) The Foucault Effect. Hemel Hempstead: Harvester Wheatsheaf, pp. 87-104.

Foucault, M. (1997a) The ethics of the concern for the self as a practice of freedom. In: Ethics, Subjectivity and Truth. Essential Works, Volume One, edited by P. Rabinow. London: Penguin Books, pp. 281-301.

Foucault, M. (1997b) What is critique? In: The Politics of Truth, edited by S. Lotringer. Los Angeles: Semiotext(e), pp. 41-82.

Foucault. M. (1980) The confession of the flesh (1977). In: Power/Knowledge Selected Interviews and Other Writings (ed. Colin Gordon). New York: Pantheon Books pp. 194-228.

Freschi, A.C. and V. Mete (2009) The political meanings of institutional deliberative experiments. Findings on the Italian case. Sociologica, 2-3 [online]. Available at: http://www.sociologica.mulino.it/journal/article/index/Article/Journal:ARTICLE:342

Fuller, C. (2013) Urban politics and the social practices of critique and justification: conceptual insights from French pragmatism. Progress in Human Geography 37(5): 639-657.

Fung, A. (2004) Empowered Participation. Reinventing Urban Democracy. Princeton, NJ: Princeton University Press.

Fung, A. (2006) Varieties of participation in complex governance. Public Administration Review, December, special issue: 66-75.

Fung, A. and E.O. Wright (2003) (eds.) Deepening Democracy: Innovations in Empowered Participatory Governance. New York: Verso. 
Gastil, J. and P. Levine (2005) The Deliberative Democracy Handbook: Strategies for Effective Civic Engagement in the 21st Century. San Francisco: Jossey-Bass.

Goodin, R. (2000) Democratic deliberation within. Philosophy \& Public Affairs, 29(1): 79-107.

Goodin, R. and J. Dryzek (2006) Deliberative impacts: the macro-political uptake of mini-publics. Politics \& Society, 34(2): 219-244.

Goven, J. (2006) Dialogue, governance and biotechnology: acknowledging the context of the conversation. Integrated Assessment Journal, 6(2): 99-116.

Guarneiros-Meza, V. and M. Geddes (2010) Local governance and participation under neoliberalism: comparative perspectives. International Journal of Urban and Regional Research, 34 (1): 115-119.

Habermas, J. (1996) Between Facts and Norms. Cambridge, MA: MIT Press.

Hagendijk. R. and A. Irwin (2006) Public deliberation and governance: engaging with science and technology in contemporary Europe. Minerva, 44: 167-184.

Hajer, M. and H. Wagenaar (2003) (eds.) Deliberative Policy Analysis. Cambridge: Cambridge University Press.

Held, D. (2006) Models of Democracy. Cambridge: Polity Press.

Hendriks, C. (2006) When the forum meets interests politics: strategic uses of public deliberation. Politics \& Society, 34(4): 571-602.

Hobson, K. 2009. On a governmentality analytics of the 'deliberative turn': material conditions, rationalities and the deliberating subject. Space and Polity, 13(3): 175-191.

Irwin, A., T.E. Jensen and K.E Jones (2013) The good, the bad and the perfect: criticizing engagement practice. Social Studies of Science 43(1): 118-135.

Jessop, B (2002) Liberalism, neo-Liberalism and urban governance: a state theoretical perspective. Antipode, 34 (3): 452-472.

Lanzara, G.F. and G. Lupo. 2013. Processi deliberativi e arene politiche locali: come le dinamiche politico-istituzionali influenzano la deliberazione. In: L. Bobbio (ed.) La Qualità della Deliberazione. Studio sui Processi Dialogici tra Cittadini. Roma: Carocci, pp. 213-249.

Lemke, T. (2003) Foucault, governmentality and critique. Rethinking Marxism 14(3): 49-64.

Lemke, T. (2007) An indigestible meal? Foucault, governmentality and state theory. Distinktion: Scandinavian Journal of Social Theory 15: 43-64.

Levidov, L. (2007) European public participation as risk governance: enhancing public accountability for agro-biotechnology policy? East Asian Science Technology and Society, 1: 1951 . 
Lewanski, R. (2013) Institutionalizing deliberative democracy: the 'Tuscany laboratory'. Journal of Public Deliberation, 9(1), article 10. Available at: http://www.publicdeliberation.net/jpd/vol9/iss1/art10.

Lezaun, J. and L. Soneryd (2007) Consulting citizens: technologies of elicitation and the mobility of publics. Public Understanding of Science, 16: 279-297.

Lövbrand, E., R. Pielke Jr. and S. Beck (2011) A democratic paradox in studies of science and technology. Science, Technology \& Human Values, 36(4): 474-496.

Malpass, A., C. Barnett, N. Clarke and P. Cloke (2007) Problematizing choice: responsible consumers and sceptical citizens. In: M. Bevir and F.Trentmann (eds.) Governance, Consumers and Citizens. New York: Palgrave MacMillan, pp. 231-56.

Mansbridge, J., J. Bohman, S. Chambers, D. Estlund, A. Føllesdal, A. Fung, C. Lafont, B. Manin and J.L. Martí (2010) The place of self-interest and the role of power in deliberative democracy. Journal of Political Philosophy, 18 (1): 64-100.

Marres, N. and J. Lezaun (2011) Materials and devices of the public: an introduction. Economy and Society 40(4): 489-509.

McKee, K. (2009) Post-Foucauldian governmentality: what does it offer critical social policy analysis?. Critical Social Policy 29: 465-486.

Melo, M. and G. Baiocchi (2006) Deliberative democracy and local governance: towards a new agenda. International Journal of Urban and Regional Research, 30(3): 587-600.

Moini, G. (2012) Teoria critica della partecipazione. Un approccio sociologico. Milano: Angeli.

Mouffe, C. (2005) On the Political. London: Routledge.

Mutz, D. (2008) Is deliberative democracy a falsifiable theory? Annual Review of Political Science, 11: $521-538$.

Nealon, J.(2008) Foucault Beyond Foucault. Power and its Intensification since 1984. Stanford, CA: Stanford University Press.

Newman, J. (2005) Participative governance and the remaking of the public sphere. In: J. Newman (ed.) Remaking Governance. Peoples, Politics and the Public Sphere. Bristol: Policy Press, pp. 119-138.

Newman, J. and J. Clarke (2009) Public, Politics and Power. London: Sage.

Niemeyer, S. and J. Dryzek (2007) The ends of deliberation: meta-consensus and inter-subjective rationality as ideal outcomes. Swiss Political Science Review, 13(4): 497-526.

Owen, D. (1999) Orientation and enlightenment: an essay on critique and genealogy. In: S. Ashenden and D. Owen (eds.) Foucault contra Habermas. London: Sage, pp. 21-44. 
Papadopoulos, Y., and P. Warin (2007) (eds.) Innovative, participatory and deliberative procedures in policy making: democratic and effective? European Journal of Political Research, 46 (4), special issue.

Parkinson, J. (2006) Deliberating in the Real World. Problems of Legitimacy in Deliberative Democracy. Oxford: Oxford University Press.

Parkinson, J. and J. Mansbridge (2012) (eds.) Deliberative Systems. Deliberative Democracy at the Large Scale. Cambridge: Cambridge University Press.

Pateman, C. (1970) Participation and Democratic Theory. Cambridge: Cambridge University Press.

Pellizzoni, L. (2012) In search of community. Political consumerism, governmentality and immunization. European Journal of Social Theory, 15(2): 221-241.

Pellizzoni, L. (2013) Une idée sur le déclin? Evaluer la nouvelle critique de la délibération publique. Participations 2: 87-118.

Pestre, D. (2008) Challenges for the democratic management of technoscience: governance, participation and the political today. Science as Culture, 17(2): 101-119.

Purcell, M. (2008) Recapturing Democracy. Neoliberalization and the Struggle for Alternative Urban Futures. New York: Routledge.

Raman, S. and R. Tutton (2010) Life, science, and biopower. Science Technology \& Human Values 35(5):711-734.

Rancière, J. (1998) Disagreement. Minneapolis: University of Minnesota Press.

Revel, M., C. Blatrix, L. Blondiaux, J.-M. Fourniau, B. Heriard-Dubreuil and R. Lefebvre (2007) Le Débat Public: Une Experience Française de Démocratie Participative. Paris: La Découverte.

Richardson, L. (2011) Cross-fertilisation of governance and governmentality in practical policy making on behaviour change. Policy \& Politics, 39(4): 533-546.

Roff, R.J. (2007) Shopping for change? Neoliberalizing activism and the limits to eating non-GMO. Agriculture and Human Values 24: 511-22.

Rose, N. (1999) Powers of Freedom. Reframing Political Thought. Cambridge: Cambridge University Press.

Rose, N. (2007) The Politics of Life Itself. Princeton: Princeton University Press.

Rosenberg, S. (2005) The empirical study of deliberative democracy: setting a research agenda. Acta Politica, 40(2): 212-224.

Rosenberg, S. (2007) Rethinking democratic deliberation: the limits and potential of citizen participation. Polity, 39(3): 335-360.

Sending, O.J. and I. Neumann (2006) Governance to governmentality: analyzing NGOs, states, and power. International Studies Quarterly, 50: 651-672. 
Silver, H., A. Scott and Y. Kazepov (2010) Participation in urban contention and deliberation. International Journal of Urban and Regional Research, 34 (3): 453-477.

Sintomer, Y. and G. Allegretti (2009) I Bilanci Partecipativi in Europa. Nuove Esperienze Democratiche nel Vecchio Continente. Roma: Ediesse.

Sintomer, Y. and J. De Maillard (2007) The limits to local participation and deliberation in the French 'politique de la ville'. European Journal of Political Research, 46: 503-529.

Sørensen, E and, J. Torfing (2005) Network governance and post-liberal democracy. Administrative Theory \& Praxis, 27(5): 197-237.

Steiner, J. (2012) The Foundations of Deliberative Democracy. Cambridge: Cambridge University Press.

Steiner, J., A. Bachtiger, M. Sporndli and M. Steenbergen (2004) Deliberative Politics in Action: Analyzing Parliamentary Discourse. Cambridge: Cambridge University Press.

Thompson, D. (2008) Deliberative democratic theory and empirical political science. Annual Review of Political Science, 11: 497-520.

Tickell, A. and J. Peck (2003) Making global rules: globalization or neoliberalization? In: J. Peck and H.W. Yeung (eds.) Remaking the Global Economy. London: Sage, pp. 163-181.

Tsouvalis, J. and C. Waterton (2012) Building 'participation' upon critique: the Loweswater Care Project, Cumbria, UK. Environmental Modelling \& Software, 36: 111-121.

Urbinati, N. (2010) Unpolitical democracy. Political Theory, 38(1): 65-92.

Van Eeten, M. (2001) The challenge ahead for deliberative democracy. Science and Public Policy, 28(6): 423-426.

Van Assche, K., R. Beunen and M. Duineveld (2013) Evolutionary Governance Theory. An Introduction. Wageningen: Wageningen University (???).

Van Mill, D. (1996) The possibility of rational outcomes from democratic discourse and procedures. Journal of Politics, 58(3): 735-752.

Williams, R. (1977) Marxism and Literature. Oxford: Oxford University Press.

Wynne, B. (2007) Public participation in science and technology: performing and obscuring a political-conceptual category mistake. East Asian Science Technology and Society, 1: 99-110. 